\title{
Deaths from abdominal trauma: analysis of 1888 forensic autopsies
}

\section{Óbitos por trauma abdominal: análise de 1888 autopsias médico-legais}

Polyanna Helena Coelho Bordonil'; Daniela Magalhães Moreira dos Santos²; Jaísa Santana Teixeira²; Leonardo Santos Bordoni-4.

\author{
A B S T R A C T
}

\begin{abstract}
Objective: to evaluate the epidemiological profile of deaths due to abdominal trauma at the Forensic Medicine Institute of Belo Horizonte, MG - Brazil. Methods: we conducted a retrospective study of the reports of deaths due to abdominal trauma autopsied from 2006 to 2011. Results: we analyzed 1.888 necropsy reports related to abdominal trauma. Penetrating trauma was more common than blunt one and gunshot wounds were more prevalent than stab wounds. Most of the individuals were male, brown-skinned, single and occupationally active. The median age was 34 years. The abdominal organs most injured in the penetrating trauma were the liver and the intestines, and in blunt trauma, the liver and the spleen. Homicide was the most prevalent circumstance of death, followed by traffic accidents, and almost half of the cases were referred to the Forensic Medicine Institute by a health unit. The blood alcohol test was positive in a third of the necropsies where it was performed. Cocaine and marijuana were the most commonly found substances in toxicology studies. Conclusion: in this sample. there was a predominance of penetrating abdominal trauma in young, brown and single men, the liver being the most injured organ.
\end{abstract}

Keywords: Autopsy. Forensic Medicine. Homicide. Abdominal Injuries.

\section{INTRODUCTION}

D eaths from external causes represent the second leading cause of mortality in Brazil and the main cause when considering individuals under the age of 351. Due to the predominance in young and productive people, external causes are the main factors responsible for potential years of life lost in Brazil ${ }^{1,2}$. Central nervous system injuries account for about half of deaths from trauma, and blood losses by about one-third ${ }^{3}$. Hemorrhage is the most common cause of avoidable death in patients treated with trauma ${ }^{4}$. Injuries to abdominal structures are an important source of bleeding and are pose special medical interest, since they present great practical difficulties for adequate diagnosis and eventual therapeutic approach, especially when there are other associated lesions ${ }^{4,5}$. This is because almost half of the bleeding in the peritoneal cavity or retroperitoneum manifests itself with few or no symptoms.
In addition, the accuracy of abdominal physical examination is low and the level of consciousness produced by hemorrhages or by the association of abdominal trauma (AT) with traumatic brain injury and/or effects of central nervous system of previously consumed substances make the adequate clinical examination even more difficulta-8. Therefore, it is emphasized that the absence of abdominal pain or signs of peritoneal irritation on physical examination does not exclude the presence of abdominal organs injuries ${ }^{9}$. Even in cases of AT with death, there are no external lesions indicative of this type of trauma in up to $31 \%$ of cases $^{10}$. These limitations together result in preventable deaths from undiagnosed abdominal injuries, even considering that the actual need for laparotomies due to closed abdominal trauma is around $5 \%{ }^{6}$.

AT can be classified basically into two types: penetrating (open) and blunt (closed) ${ }^{11}$. The penetrating is the one in which the entry of the aggressive agent

1 - Civil State Police of Minas Gerais, Coroner's Office, Ribeirão das Neves, MG, Brazil. 2 - José Bonifácio Lafayette de Andrada Foundation, Faculty of Medicine, Barbacena, MG, Brazil. 3 - Civil State Police of Minas Gerais, Forensic Medicine Institute, Belo Horizonte, MG, Brazil. 4 - University of Ouro Preto, School of Medicine, Ouro Preto, MG, Brazil. 
into the peritoneal cavity occurs, in most cases a firearm projectile (gunshot) or a laminated object (stabbing) and it exerts its effects directly over the viscera. In this case, the organs most affected are the small intestine, colon and liver ${ }^{11}$. In blunt AT there is no penetration of the aggressive agent into the peritoneal cavity. The effects of the offending agent in this case are transmitted to the viscera through the abdominal wall, or by kickback and deceleration. The prevalence of abdominal viscera lesions in cases of blunt trauma is around 13\%, the spleen and liver being the most damaged structures in this situation? ${ }^{9}$.

Considering the global epidemiology of AT, the majority of cases treated in hospital units are blunt trauma, but in regions with high homicide rates, such as large Brazilian cities and their metropolitan regions, penetrating trauma may be more frequent ${ }^{8,9,11,12}$. Around $75 \%$ of cases of blunt AT result from traffic accidents, with assaults accounting for $15 \%$ and falls for the rest ${ }^{9}$. The mean mortality rate of AF due to gunshot wounds, of around $7 \%$, is higher than in cases of stabbing injuries and blunt trauma ${ }^{13}$.

In recent years, in parallel with the increase in intentional and unintentional interpersonal violence in our country, the AT's incidence has also increased ${ }^{2,11}$. In deaths due to external causes, or in cases that are suspected of being such, a legal medical necropsy is mandatory by our legislation ${ }^{14,15}$. In these situations, completing the death certificate is a responsibility of the coroner $^{16}$. Data from necropsy medical-legal reports can provide important information in the epidemiological study of AT, since unlike the information available in the Mortality Information System (MIS) of the Ministry of Health, it contains a detailed description of the lesions found, as well as other important information on the context of death, such as data on the search for alcohol content and other substances consumed prior to death, such as illicit drugs. In addition, despite advances in imaging studies, necropsy remains the "gold standard" for the confirmation of clinical and surgical diagnoses, including AT cases $^{7}$. The ideal, therefore, for a complete epidemiological investigation on mortality by AT and for the other external causes is that medical-legal reports be a source of complementary information to the MIS, as recommended by the World Health Organization ${ }^{7,17}$.
Considering the importance of AT, as well as the deficiency of national information involving necroscopic studies with this cause of death, this research aimed to evaluate its epidemiological profile at the Belo Horizonte Forensic Medical Institute (IML-BH).

\section{METHODS}

We conducted a retrospective study, in which were evaluated the reports of deaths from abdominal trauma necropsied in the IML-BH from January 1, 2006 to December 31, 2011. Located in the capital of the state of Minas Gerais, IML-BH is a government department linked to the Civil Police, being responsible for the medical investigation of all deaths due to external causes occurred in the capital of the state and in most of the municipalities of its Metropolitan Region (RMBH). Necroscopic forensic investigation of all deaths from violent causes is mandated by federal law in Brazil14. Belo Horizonte (BH) is the sixth most populous city in Brazil, with an estimated population of $2,513,451$ inhabitants for the year $2016^{18}$. Its metropolitan area is the third most populous in the country, with an estimated population of 5,829,921 inhabitants in the year $2015^{18}$.

The deaths analyzed in this study were those whose cause directly involved AT. We also included cases with trauma in other body regions, such as the head, limbs and thorax, as long as associated with AT in the mechanism of death. We excluded cases that presented technical problems in the completion of the reports, the duplicates, the cases whose types of trauma could not be precisely defined, and those in which the death was due to trauma occurring exclusively in other body regions other than the abdomen.

We analyzed data on seasonality (year, month and day of the week), demographics (gender, age, marital status, occupational characteristics, skin color, and residence), deaths characteristics (circumstance, type of trauma, trauma mechanism, signs of medical care) and complementary tests performed (toxicological and blood alcoholic findings). Not all such variables were available in all reports.

We considered that the deceased received medical care prior to death when they came from 
health facilities, when they were referred along with medical reports or when they showed signs of recent medical procedures such as vascular punctures, signs of orotracheal intubation, surgical wounds, placement of drains, among others. Even in cases that received medical attention, trauma indexes were not available.

We performed statistical analyzes using the STATA software, version 9.2. We obtained frequency, position and central tendency measurements, and used the Chi-square and Fisher's exact tests for comparison of qualitative variables and the Kruskal-Wallis test for comparison of quantitative ones, in order to evaluate possible associations. The level of significance was set at 0.05 .

The project was approved by the Ethics in Research Committee of the Hospital Foundation of the State of Minas Gerais, under the protocol number 23100813.2.0000.5119.

\section{RESULTS}

We recovered 1888 reports of fatal victims of abdominal trauma (AT), corresponding to $5.2 \%$ of the total necropsies performed at IML-BH in the studied period (2006 to 2011). The underlying cause of death was hemorrhage and its direct complications in 1884 cases, and trauma-related infectious complications in four. Penetrating trauma was more common (78.76\%) than blunt trauma (401 cases - Table 1). Of the penetrating trauma cases, gunshot wounds were more prevalent (89.28\%) than stabbing wounds (159 cases).

The highest proportion of necropsies occurred on Sundays (23.94\%), in January $(9.75 \%)$ and in 2007 (23.41\%). The lowest number of autopsies took place on Fridays (165 cases), in the months of September (128) and in the year of 2010 (209).

The majority of the individuals were male, brown, single, were 49 years old (90.79\%), occupationally active, had completed high school as a minimum level of education required to practice their profession and did not reside in the city of Belo Horizonte (Table 1). We highlight the significantly higher proportion of necropsies in males, brown or black, single and residing in Belo Horizonte $(\mathrm{BH})$ related to the deaths due to penetrating trauma compared with blunt trauma (Table 1). There were also proportionally more men, unmarried and $\mathrm{BH}$ residents whose death was related to gunshots when compared with those whose death cause was stabbing (Table 2). The mean age found in the sample was $29.73 \pm 12.86$ years, and the extremes of age were one and 90 years. The mean age of victims of penetrating trauma was significantly lower (27.87 \pm 10.62 years) than that of blunt trauma $(36.64 \pm 17.32$ years) $(p<0.001)$. The mean age of gunshot victims was significantly lower $(27.19 \pm 10.15$ years) than that of stabbed individuals $(33.70 \pm 12.66)$ $(p<0.001)$.

Homicide was the most prevalent death (78.55\%). Health units sent most of such cases to the IML-BH (47.99\%), although most necropsies did not undergo medical procedures prior to death (77.12\%) (Figure 1). For blunt trauma, there was a significantly higher proportion of deaths due to traffic accidents $(83.29 \%)$ and signs of receiving medical assistance prior to death (56.86\%) compared to penetrating trauma (Figure 1). There were proportionately fewer individuals coming from residential addresses who died due to gunshots compared with those whose death was due to stabbing (Table 2). Among the homicide cases, we observed a higher percentage of males $(92.51 \%)$.

The data obtained with complementary exams performed in the AT victims, regarding alcohol and illicit drugs use, can be seen in table 3 .

There were proportionally more hepatic and splenic lesions in blunt traumas (315 and 170 cases, respectively) than in the penetrating trauma (1293 and 382 cases, respectively) ( $p=0.000$ for both) (Figure 2 ). Although the most injured abdominal organ in penetrating trauma was the liver, there were predominantly more lesions in the intestines (853 cases), stomach (351 cases) and blood vessels (312 cases) of individuals victims of penetrating trauma when compared with blunt trauma (75, 17 and 31 cases, respectively) ( $p=0.000$ for all variables). The kidneys were proportionally more affected in cases resulting from stab wounds (17 cases) compared with those related to gunshots (82 necropsies) $(p=0.04)$. Intestinal lesions were more common in gunshot (709 cases) than in stabbing wounds (69 cases) ( $p=0.006)$. We observed concomitant lesions in more than one abdominal organ in some individuals. 
Table 1. Sociodemographic characteristics of abdominal trauma deaths according to trauma type (IML-BH, 2006 to 2011).

\begin{tabular}{|c|c|c|c|c|c|c|}
\hline & \multicolumn{2}{|c|}{$\begin{array}{c}\text { Penetrating } \\
\text { trauma }\end{array}$} & \multicolumn{2}{|c|}{ Blunt trauma } & \multicolumn{2}{|c|}{ Total } \\
\hline & $N$ & $\%$ & $N$ & $\%$ & $\mathrm{~N}$ & $\%$ \\
\hline \multicolumn{7}{|l|}{ Gender a } \\
\hline Male & 1377 & 92.60 & 334 & 83.29 & 1711 & 90.63 \\
\hline Female & 110 & 7.40 & 67 & 16.71 & 177 & 9.37 \\
\hline \multicolumn{7}{|l|}{ Age group ${ }^{a}$} \\
\hline$=18$ years & 160 & 10.76 & 28 & 6.98 & 188 & 9.96 \\
\hline $18-29$ years & 802 & 53.93 & 138 & 34.41 & 940 & 49.79 \\
\hline 30-39 years & 329 & 22.13 & 81 & 20.20 & 410 & 21.72 \\
\hline 40-49 years & 114 & 7.67 & 62 & 15.46 & 176 & 9.32 \\
\hline $50-59$ years & 43 & 2.89 & 44 & 10.97 & 87 & 4.61 \\
\hline 60-69 years & 19 & 1.28 & 19 & 4.74 & 38 & 2.01 \\
\hline$=70$ years & 8 & 0.54 & 24 & 5.99 & 32 & 1.69 \\
\hline Unspecified & 12 & 0.81 & 5 & 1.25 & 17 & 0.90 \\
\hline \multicolumn{7}{|l|}{ Skin color a } \\
\hline White & 346 & 23.27 & 170 & 42.39 & 516 & 27.33 \\
\hline Brown & 964 & 64.83 & 207 & 51.62 & 1171 & 62.02 \\
\hline Black & 171 & 11.50 & 24 & 5.99 & 195 & 10.33 \\
\hline Unspecified & 6 & 0.40 & 0 & 0 & 6 & 0.32 \\
\hline \multicolumn{7}{|l|}{ Marital status ${ }^{a}$} \\
\hline Single & 1220 & 82.04 & 242 & 60.35 & 1462 & 77.44 \\
\hline Married/stable & 176 & 11.84 & 115 & 28.68 & 291 & 15.41 \\
\hline Widow(er) & 8 & 0.54 & 16 & 3.99 & 24 & 1.27 \\
\hline Divorced or separated & 38 & 2.55 & 18 & 4.49 & 56 & 2.97 \\
\hline Unspecified & 45 & 3.03 & 10 & 2.49 & 55 & 2.91 \\
\hline \multicolumn{7}{|l|}{ Municipality of residence ${ }^{b}$} \\
\hline Belo Horizonte & 695 & 46.74 & 162 & 40.4 & 857 & 45.39 \\
\hline Other & 749 & 50.37 & 229 & 57.11 & 978 & 51.8 \\
\hline Unspecified & 43 & 2.89 & 10 & 2.49 & 53 & 2.81 \\
\hline \multicolumn{7}{|l|}{ Occupationally active ${ }^{c}$} \\
\hline Yes & 1122 & 75.45 & 297 & 74.07 & 1419 & 75.16 \\
\hline No & 319 & 21.45 & 91 & 22.69 & 410 & 21.72 \\
\hline Unspecified & 46 & 3.10 & 13 & 3.24 & 59 & 3.12 \\
\hline \multicolumn{7}{|c|}{ Education required for the exercise of profession ${ }^{a}$} \\
\hline High-school & 1115 & 74.99 & 300 & 74.82 & 1415 & 74.95 \\
\hline College & 0 & 0 & 11 & 2.74 & 11 & 0.58 \\
\hline Undefined & 24 & 1.61 & 11 & 2.74 & 35 & 1.85 \\
\hline Home/Student/without occupation & 300 & 20.17 & 60 & 14.96 & 360 & 19.07 \\
\hline Unspecified & 48 & 3.23 & 19 & 4.74 & 67 & 3.55 \\
\hline
\end{tabular}

$\mathrm{p}={ }^{\mathrm{a}} 0.000 ;{ }^{\mathrm{b}} 0.019 ;{ }^{c} 0.581$. 
Table 2. Comparison of penetrating abdominal trauma victims according to trauma mechanism (IML-BH, 2006 to 2011).

\begin{tabular}{|c|c|c|c|c|}
\hline & \multicolumn{2}{|c|}{ Gunshots * } & \multicolumn{2}{|c|}{ Stabbings ** } \\
\hline & $\mathrm{N}$ & $\%$ & $\mathrm{~N}$ & $\%$ \\
\hline \multicolumn{5}{|l|}{ Gender ${ }^{a}$} \\
\hline Male & 1244 & 93.96 & 129 & 81.13 \\
\hline Female & 80 & 6.04 & 30 & 18.87 \\
\hline \multicolumn{5}{|l|}{ Marital status ${ }^{b}$} \\
\hline Single & 1100 & 85.14 & 116 & 79.45 \\
\hline Married/stable & 158 & 12.23 & 18 & 12.33 \\
\hline Widow(er) & 7 & 0.54 & 1 & 0.68 \\
\hline Divorced or separated & 27 & 2.09 & 11 & 7.53 \\
\hline \multicolumn{5}{|l|}{ Residence $^{c}$} \\
\hline Belo Horizonte & 638 & 49.34 & 55 & 37.41 \\
\hline Other & 655 & 50.66 & 92 & 62.59 \\
\hline \multicolumn{5}{|c|}{ Place of origin of the corpse ${ }^{d}$} \\
\hline Residential address & 107 & 8.16 & 29 & 18.24 \\
\hline Health unit & 613 & 46.72 & 64 & 40.25 \\
\hline Public venus & 563 & 42.91 & 63 & 39.62 \\
\hline Business address & 29 & 2.21 & 3 & 1.89 \\
\hline \multicolumn{5}{|l|}{ Alcohol content Result ${ }^{a}$} \\
\hline Positive & 300 & 30.40 & 67 & 59.29 \\
\hline Negative & 687 & 69.60 & 46 & 40.71 \\
\hline \multicolumn{5}{|l|}{ Toxicology Result ${ }^{a}$} \\
\hline Positive & 543 & 54.63 & 38 & 32.20 \\
\hline Negative & 451 & 45.37 & 80 & 67.80 \\
\hline
\end{tabular}

* Gunshots $=$ Penetrating-blunt actions. ${ }^{*}$ S Stabbings = Cutting/perforating-cutting actions. $\mathrm{p}={ }^{\mathrm{a}} 0.000 ;{ }^{\mathrm{b}} 0.002 ;{ }^{\mathrm{c}} 0.006 ;{ }^{\mathrm{d}} 0.001$.

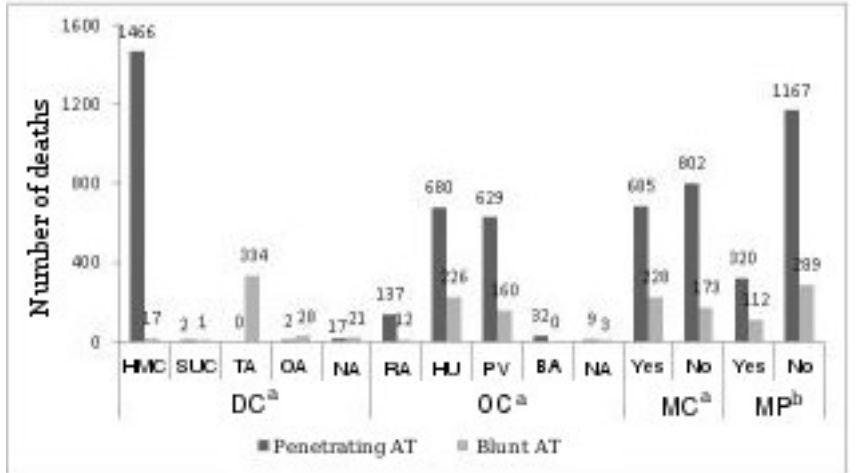

Figure 1. Circumstances of deaths due to abdominal trauma and presence of medical care according to trauma type.

$D C=$ Death circumstance. $H M C=$ homicides. SUC = Suicides. TA= Traffic Accident $O A=$ Other accidents. $N A=$ Data not available. $O C=$ Origin of the corpse. $R A=R e-$ sidential address. $H U=$ Health unit. $P V=$ Public venue. $B A=$ Business address. $M C=$ Signs of medical care. MP= Signs of medical procedures. $p=a$ 0 0.000, b 0.007 .

We observed head injuries in 347 cases and thoracic organ injuries in 1503 individuals. Although the lungs were the most affected extra-abdominal organs in all death mechanisms, we observed more injuries to the head and heart of the victims of penetrating trauma (346 and 722 cases, respectively) than in the victims of blunt trauma (49 102 cases, respectively) ( $p=0.000$ for both) (Figure 3). Even with the presence of these associated lesions, they were not attributed by the coroners as exclusively responsible for the deaths. It is noteworthy that there were concomitant lesions in more than one body segment in some autopsies and that multiple organ lesions were observed in some individuals.

For blunt trauma, in cases of both hepatic and splenic lesions, the limbs' fractures most frequently found were those of lower limbs, especially of the femur (49 cases $/ 15.6 \%$ and 24 cases $/ 14.2 \%$, respectively) and tibia/fibula (39 cases/12.4\% and 18 cases/10.6\%, respectively). 
The mean number of gunshot wounds to the abdomen was $1.33 \pm 1.28$, with the median of one entry orifice, first quartile of one, and third quartile of two entry orifices. The highest number of entry lesions observed in the same individual in the abdomen and/or chest were 15. The mean number of stab wounds was $2.76 \pm 4.41$. It is noteworthy that gunshot and stabbing thorax entries were also responsible for abdominal organ lesions.

Table 3. Complementary exams in abdominal trauma deaths according to trauma type (IML-BH, 2006 to 2011).

\begin{tabular}{|c|c|c|c|c|c|c|}
\hline & \multicolumn{2}{|c|}{ Penetrating trauma } & \multicolumn{2}{|c|}{ Blunt trauma } & \multicolumn{2}{|c|}{ Total } \\
\hline & $\mathrm{N}$ & $\%$ & $\mathrm{~N}$ & $\%$ & $N$ & $\%$ \\
\hline \multicolumn{7}{|l|}{ Alcohol content ${ }^{a}$} \\
\hline Examined & 1102 & 74.11 & 329 & 82.04 & 1431 & 75.79 \\
\hline Not examined & 385 & 25.89 & 72 & 17.96 & 457 & 24.21 \\
\hline \multicolumn{7}{|c|}{ Alcohol content-Result ${ }^{b}$} \\
\hline Positive & 367 & 33.30 & 117 & 35.56 & 484 & 33.82 \\
\hline Negative & 734 & 66.61 & 212 & 64.44 & 946 & 66.11 \\
\hline Unspecified & 1 & 0.09 & 0 & 0 & 1 & 0.07 \\
\hline \multicolumn{7}{|l|}{ Toxicology c } \\
\hline Examined & 1115 & 74.98 & 186 & 46.38 & 1301 & 68.91 \\
\hline Not examined & 372 & 25.02 & 215 & 53.62 & 587 & 31.09 \\
\hline \multicolumn{7}{|c|}{ Toxicology Result ${ }^{a}$} \\
\hline Positive & 583 & 52.29 & 32 & 17.20 & 615 & 47.27 \\
\hline Negative & 531 & 47.62 & 154 & 82.80 & 685 & 52.65 \\
\hline Unspecified & 1 & 0.09 & 0 & 0 & 1 & 0.08 \\
\hline
\end{tabular}

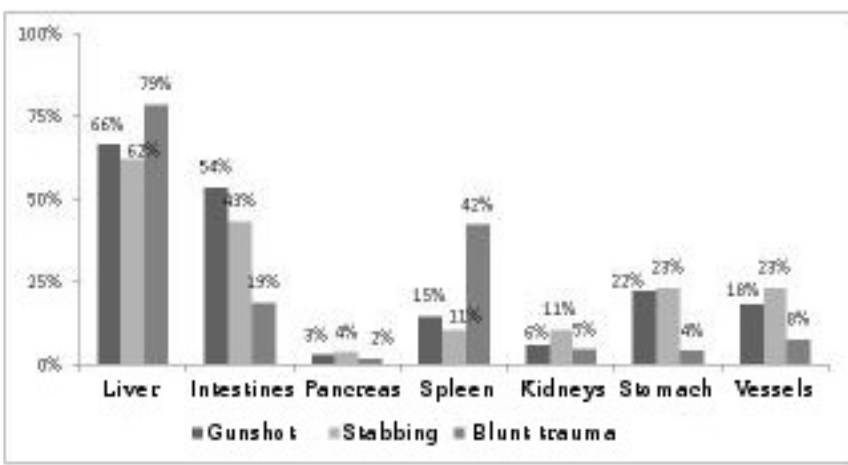

Figure 2. Abdominal organ injuries in fatal victims of abdominal trauma according to trauma mechanism (IML-BH, 2006-2011).

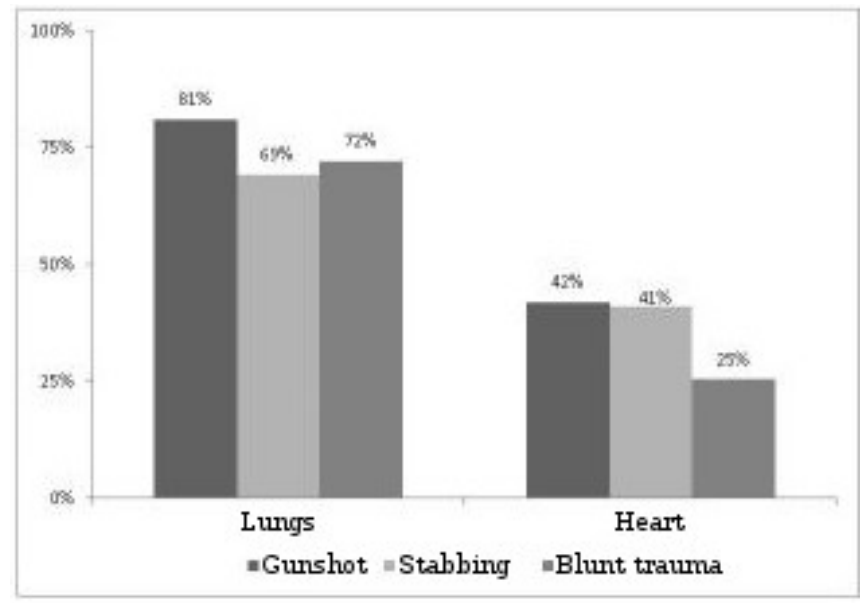

Figure 3. Thoracic organ injuries in fatal victims of abdominal trauma according to trauma mechanism (IML-BH, 2006-2011). 


\section{DISCUSSION}

In our sample, penetrating trauma was much more frequent (78.8\%) than blunt one. A study carried out with victims of AT submitted to exploratory laparotomy in the city of Florianópolis also found a majority (68.6\%) of cases related to penetrating trauma ${ }^{19}$. However, these percentages vary when data from different cities and countries are observed. Retrospective studies of AT victims in the Portuguese city of Porto and in Kathmandu, Nepal, indicated that $85.3 \%$ and $82.5 \%$ were cases of blunt trauma, respectively ${ }^{20,21}$. The almost inverse percentages observed in these countries when compared with our sample reflect the different circumstances related to AT in each locality. Most cases of IML-BH autopsies were related to homicides (78.6\%), especially cases of penetrating trauma, whereas in the Portuguese study, traffic accidents and falls were the most prevalent (76.1\%), and in the Nepalese study, traffic accidents were the majority $(87.5 \%)$, which are more related to blunt trauma20,21. In addition, our sample consisted only of fatal cases, while the Portuguese series also considered those who survived, and penetrating trauma displayed higher average mortality ${ }^{20}$.

Considering all cases of penetrating trauma that receive medical attention, those due to stabbing are, in general, more frequent than cases related to gunshot wounds ${ }^{12}$. However, in the IML-BH sample, as well as in the data from the Florianópolis study ${ }^{19}$, it was observed that gunshot wounds were more frequent than stabbing wounds. The IML-BH greater proportion of gunshot wounds among the penetrating traumas is justified by the fact that abdominal injuries gunshots represent up to $90 \%$ of the mortality in penetrating $A T^{13}$. By transferring increased kinetic energy to organs and tissues, abdominal trauma due to gunshots results in a mortality rate about eight times higher than that related to stabbing injuries ${ }^{22}$. Although in the cases of IML-BH the penetrating trauma due to gunshots represented a percentage greater than that found in the Florianópolis study $(89.3 \%$ and $75.6 \%$, respectively) ${ }^{19}$, that study also evaluated patients who survived the trauma $(89.8 \%$ of those who underwent surgery), which may justify this dif- ference ${ }^{19}$.

The majority of individuals necropsied in IML-BH were male $(90.3 \%)$, with a mean age of 34 years. In the study conducted in Porto, males were also more prevalent $(74.2 \%)$ and the mean age was 42.6 years $^{20}$. The higher male prevalence and the lower mean age observed in our sample are a reflection of the large proportion of homicides and penetrating trauma among the cases of IML-BH, situations in which male and younger victims are more commonly observed ${ }^{2}$. It should be noted that, in the Portuguese series, the most frequent trauma circumstance was traffic accident, which covers a larger age group and a larger female contingent ${ }^{2,20}$. In a case-control study conducted in the city of Curitiba, it was observed that in deaths due to blunt AT, males accounted for $77.4 \%$ of the cases and the mean age observed was 33.2 years ${ }^{23}$, results similar to those found in our sample if considered only cases of blunt AT (83.29\% men and mean age 36.64 years). In a work involving homicide victims in Cape Town, $90.2 \%$ of the cases were men, a percentage practically identical to that of our sample ${ }^{24}$.

In the period from 2002 to 2012, the number of homicides registered in Brazil increased from 49,695 to 56,337 , an increase of $13.4 \%^{2}$. In Minas Gerais, homicides increased by $7.1 \%$ in the same period $^{2}$. For the year 2012, Belo Horizonte had a total homicide rate of 40.6 per 100 thousand inhabitants, but when considering only homicides in individuals under 29 years, the rate more than doubles $(91.9 / 100$ thousand $)^{2}$. The relationship between AT and male gender, especially in cases of gunshot homicides, is due to men being more involved in criminal use of firearms (widely available in our country), in addition to consuming proportionally more alcohol and illicit drugs than women, factors that increase aggressiveness and the adoption of violence-risky behaviors ${ }^{2,21}$. In 2012, the national rate of 54.3 homicides per 100,000 male residents was about ten times higher than the female rate $(4.8 / 100 \text { thousand })^{2}$. It is noteworthy that, while women accounted for only $6 \%$ of the gunshot victims in our sample, $18.9 \%$ were stabbing victims, which may suggest the passionality of assaults against women, which occur frequently in the domestic sphere, where knives are easily accessible to the aggres- 
sor $^{25}$. While almost half of all homicides occur in public spaces, less than a third of female homicides occur in such locations, the victim's home being the site of $27.1 \%$ of female homicides ${ }^{25}$. Such data together may also justify the larger proportion of stabbed individuals coming from their home addresses found in our sample compared with those whose death was related to gunshots.

Only $1.16 \%$ of the cases of homicide with AT autopsied in the IML-BH involved blunt trauma. A South African study of victims of blunt trauma homicides showed that, although $20 \%$ had some type of abdominal injury, in only $7 \%$ there were no significant associated cranial lesions ${ }^{24}$. Tunisian cases with homicide data from 2005 to 2014 indicated that blunt trauma was the second most common death mechanism $(24.8 \%)^{26}$.

Most individuals (90.79\%) were up to 49 years of age (about $50 \%$ in the age group $18-29$ years), which may be related to most individuals being single. The mean age of victims of penetrating trauma in homicides, 27.87 years, was significantly lower than that of injuries resulting from blunt trauma in traffic accidents, 36.64 years, which agrees with the national statistics on mortality from external causes. When considering the deaths of individuals under 29 in Brazil, in 2012, 71.1\% were due to external causes, with $38.7 \%$ of homicides ${ }^{2}$.

Most of the necropsied had brown skin, both in cases of penetrating trauma (64.8\%) and in blunt traumas (51.6\%). A study conducted in the city of Salvador with deaths from external causes from 1998 to 2003 indicated that men with brown skin lose more potential years of life due to violence than the black and white population ${ }^{27}$. Such differences observed in potential years of life lost per 100,000 inhabitants among different skin color groups remained even after age standardization, and brown and black men, in that order, died earlier due to all types of external causes ${ }^{27}$. Whites tend to have a better average schooling rate than browns and blacks, a better socioeconomic level, better access to health promotion measures and less exposure to violence ${ }^{27}$.

Weekends concentrate most of the cases of external deaths, especially homicides, in several studies $^{24,28-30}$. In our sample, where the death circums- tance was predominantly homicide, almost a quarter (23.9\%) of autopsies occurred on Sundays. Epidemiological data on homicides in the state of São Paulo, in Cape Town, South Africa, and in the city of Ilhéus, Bahia, indicated that Sundays also concentrated the highest proportional number of cases $(20 \%, 23.7 \%$ and $32 \%$, respectively). This corroborates that the weekend is the period of greatest exposure to risk factors for violence, such as the consumption of alcohol and illicit drugs, as well as the permanence in environments conducive to interpersonal conflicts ${ }^{28}$. The same reasoning applies to those periods with longer and hotter days, especially January, which concentrated $9.8 \%$ of IML-BH cases.

At the Getúlio Vargas State Hospital, in the city of Rio de Janeiro (HGV-RJ), with 1688 patients operated on with blunt AT, the spleen was the most damaged abdominal organ, followed by the liver, intestines (small and large), bladder and the kidneys ${ }^{11}$. A study in Santa Catarina State patients submitted to exploratory laparotomy indicated splenic lesions twice as frequent as hepatic ones in blunt trauma ${ }^{19}$. In the IML-BH data, the liver was the most affected viscera in blunt AT, with the spleen in second, followed by the intestines and large abdominal vessels. Similarly, another necroscopic (Nepalese) study also indicated a higher percentage of hepatic lesions (57.5\%) than spleen ones $(37.5 \%)^{10}$. Hepatic lesions produce potentially larger hemorrhages than splenic injuries, and as our casuistry involved only those who died, the considerably higher percentage of liver lesions is explained. A case-control study with victims of blunt AT who received medical care showed that, for most of deaths preceded by hemodynamic instability, there were lesions of massive abdominal viscera ${ }^{23}$. The retrospective study with polytrauma patients who presented severe traumatic brain injury demonstrated that the liver was the most affected abdominal viscus in cases with associated AT and signaled that hemodynamic instability at hospital admission indicated a six-fold increased risk for the presence of abdominal viscera lesions compared with patients who were hemodynamically stable ${ }^{6}$. Hemorrhage, with its direct complications, was responsible for almost all deaths in our sample (1884 cases). 
In cases of blunt AT necropsied in the IML-BH, femoral fractures were observed in $15.6 \%$ of individuals with hepatic lesions and in $14.2 \%$ of cases with splenic lesions. Femur fracture was the bone lesion most frequently associated with abdominal viscera lesions in our data, which is widely corroborated by the literature. A systematic review of 10,757 patients with blunt trauma indicated that the concomitant presence of femoral fracture increased the relative risk of visceral abdominal injury by 2.9 times $^{9}$. The risk of abdominal visceral injury increased 58-fold when there were surgical orthopedic lesions in polytraumatized patients with cranio-encephalic trauma6.

The proportion of lesions in large abdominal (arterial and venous) vessels observed in our sample, of $8 \%$, was higher than that found in the Rio de Janeiro series in cases operated due to closed AT $(0.7 \%) 11$, but the severity of volume loss in necropsied cases explains its greater prevalence in our data.

The second most common circumstance of death in the IML-BH data were traffic accidents, with all AT deaths in this group due to blunt trauma. The intestines, especially the small one, are the most damaged abdominal viscera in blunt AT, being affected in up to $3 \%$ of the $\operatorname{cases}^{31,32}$. A prospective multicenter American study has indicated that victims of traffic accidents are 1.5 times more likely to present abdominal hollow viscera lesions than in other blunt trauma mechanisms ${ }^{32}$. In addition, the mortality rate ranges from $15 \%$ for small intestine lesions to around 19\% for rectal lesions ${ }^{33}$. These data, together, corroborate what we observed, a high percentage of intestinal lesions in blunt AT (19\%), which reflects large energy transfers in traffic accidents in fatal cases. For cases of blunt trauma with isolated abdominal hollow viscera lesions, the Paraná case-control study indicated that this is a good prognostic factor, even in lesions that require surgical intervention ${ }^{23}$. That is, usually in fatal cases of blunt AT, injuries other than those of hollow viscera are responsible for death. We observed this in our sample, where lesions of intestines in blunt AT were generally associated with other visceral lesions, since in none of these cases the cause of death was exclusively determined by intestinal lesions.

Gastric lesions in blunt AT are observed in up to $1.7 \%$ of cases, a low percentage explained by the relatively protected anatomical position of this organ ${ }^{33,34}$. Although relatively rare, they present high mortality, varying from $28 \%$ to $66 \%^{31-33}$. This justifies the higher percentage (4\%) observed in the IML-BH data, since only fatal cases, naturally more severe, were studied. Because it presents a protected position, a greater transfer of energy is necessary to produce a gastric lesion, and in about $95 \%$ of the cases, there are other associated lesions, such as of the spleen and lungs ${ }^{33-35}$. Like with intestinal lesions, there were no deaths exclusively due to gastric lesions in our data.

The most damaged organs in cases of penetrating AT necropsied in IML-BH were the liver, followed by the intestines, both in gunshot and stabbing victims. Although there are regional variations, the reverse is epidemiologically observed, with intestines more damaged than the liver in this type of trauma ${ }^{12,13,19}$. A HGV-RJ series with 4478 patients operated on due to penetrating AT indicated that the intestines (duodenum, jejunum, ileum and colon) were the most commonly affected abdominal organs, followed by the liver, stomach and kidneys ${ }^{11}$. The same was observed in a Florianópolis study ${ }^{19}$. Liver lesions by penetrating AT show higher mortality rates than intestinal lesions ${ }^{13,36}$, reaching $22 \%$ in gunshot wound cases and $8 \%$ in stabbing ones ${ }^{36}$, which explains their high prevalence in IML-BH penetrating necropsies. Although the liver was the most commonly injured abdominal organ in penetrating AT in our sample, there were predominantly more lesions in the intestines, stomach and large abdominal vessels of individuals who were victims of penetrating trauma compared with victims of blunt trauma. It is noteworthy that isolated hepatic lesions due to gunshots are not common, these being usually associated with other lesions, particularly the right lung, diaphragm, right kidney and small intestine ${ }^{37}$. In our sample, $81 \%$ of the victims had lung injuries associated with the abdominal trauma.

Abdominal vascular injuries due to penetrating trauma, especially those located in the upper portion of the abdomen, present a high mortality rate because they produce massive hemorrhage and present a high incidence of associated lesions ${ }^{38}$. The mortality rates of abdominal vascular injuries can reach 53\% 
in cases of shooting and $32 \%$ in cases of stabbing ${ }^{36}$. The HGV-RJ data showed a low percentage of lesions of large abdominal vessels in open trauma, with only $2.5 \%$ of cases presenting lesions of the inferior vena cava and lower percentages with lesions of other important abdominal vessels ${ }^{11}$. In the Florianópolis study with patients operated on due to penetrating AT, vascular lesions were observed in $5.4 \%$ of cases $^{19}$. We should emphasize that the series from Rio and Florianópolis involved both patients who died and those who recovered from the surgical procedures. In our sample, we observed lesions of large abdominal arterial or venous vessels in larger proportions (18\% of the victims of gunshots and $23 \%$ of the victims of stabbing), since the main immediate cause of death in AT is blood loss.

The mean number of gunshot entry wounds that caused lesions to abdominal viscera was 1.3 and the mean of stab wounds was 2.8. Multiple stabbing wounds are found in up to one-third of patients receiving medical care for this type of trauma ${ }^{12}$. Since the transfer of kinetic energy to the tissues is much greater in the gunshot injuries ${ }^{13}$, the smaller number of perforations is sufficient to cause serious lesions causing death. One of the consequences of this is that the kidneys, which are retroperitoneal and, therefore, deeper structures, were proportionally more injured in cases resulting from stabbing compared with those related to gunshots.

The proportion of $33.8 \%$ positivity in the studied blood alcohol levels in our sample was similar to that found in a retrospective study that used data from all violent deaths occurred in the state of São Paulo in 2006, of $36.9 \%{ }^{39}$. Such data may indicate common cultural traits related to the consumption of this substance among different units of the Brazilian Federation. The mean blood alcohol content in the study from São Paulo, $18 \mathrm{dg} / \mathrm{L}$, was higher than that found in our sample, $15.3 \mathrm{dg} / \mathrm{L}$, although it involved a larger geographical area and all causes of external deaths ${ }^{39}$. Another study, based on data from 2042 homicide victims in the city of São Paulo, found a positive reaction to ethyl alcohol in $43 \%$ of cases, with an average of $15.5 \mathrm{dg} / \mathrm{L}^{40}$, practically the same average value of our data. The majority of cases of blunt
AT of the IML-BH presented an average higher alcohol content, of $18.54 \mathrm{dg} / \mathrm{L}$. Knowing that such cases were related to traffic accidents, we highlight the probable association between alcohol consumption and this circumstance of death, already widely described in the literature ${ }^{41}$. The IML-BH data also showed proportionally more positive cases of alcohol consumption, and with higher averages, $20.4 \mathrm{dg} / \mathrm{L}$, in stabbing-related deaths than in gunshot victims, $12.17 \mathrm{dg} / \mathrm{L}$, which was also observed in the study with homicide victims in the city of São Paulo ${ }^{40}$. Interpersonal assaults with the use of knives generally involve more passion than the violence related to firearms and, in this context, is related to higher means of alcoholism positivity ${ }^{40}$. Alcohol is the most commonly found substance in forensic toxicology analyzes and is an important risk factor for violent deaths, being directly involved in up to $50 \%$ of such deaths ${ }^{39,41}$. Although alcoholic drunkenness is a syndrome of essentially clinical diagnosis, and non-laboratory, with a blood alcohol content of $15 \mathrm{dg} / \mathrm{L}$, most people will present important neurological changes, such as emotional instability, loss of critical thinking, variable memory deficits, sleepiness and motor deficits, among others ${ }^{41}$. These effects put the individual at risk for violent behaviors or for negligence with situations of potential risk, such as accidents and assaults ${ }^{39,41}$.

The drugs most commonly found in IML-BH toxicological investigations were cocaine and marijuana, the most commonly used illicit drugs in Brazil ${ }^{42,43}$. Similarly, in the study carried out with data from the MIS and IML-BH, which evaluated cases of homicides occurred in Belo Horizonte from 2000 to 2009, it was observed that cocaine was the most common illicit drug $^{43}$. A meta-analysis of 28,868 toxicological investigations of 30,482 homicide victims in five countries found that cocaine was the most common illicit drug, with $11 \%$ of cases, followed by marijuana, with $6 \%$, cocaine being related to an increased risk of death by gunshot wounds ${ }^{44}$. Similarly, in the IML-BH data, there were proportionally more positive results in the toxicology exams of individuals who died due to gunshots compared with those whose death was caused by stabbing wounds. The percentage of cocaine -positive cases in our sample, $40.9 \%$, was higher than 
that found in homicide victims in the American city of New York, 31\% ${ }^{45}$, almost double the percentage found in homicide victims in the state, $20.9 \%{ }^{46}$, and almost quadrupled that found in the meta-analysis with data from five different countries ${ }^{44}$. Although we studied a more specific group of individuals, we highlight the relation between cocaine and violent death, be it in cases of homicide or in cases of accidents or suicides ${ }^{46}$. The meeting of 20 individuals with simultaneously positive toxicological examination for cocaine and marijuana reaffirms the association between these two drugs and violent deaths ${ }^{46}$. The consumption of illicit drugs is an important risk factor for deaths due to external causes, not only due to its effects on the central nervous system and consequent behavioral changes, but also to exposing the user to situations of violence related to the acquisition and commercialization of the substance ${ }^{43}$. Although there is evidence that Brazilian and Ameri- can consumption of marijuana is greater than that of cocaine, its stimulating effects on the central nervous system, different from the predominantly inhibitory effects of marijuana, predispose the user to situations of violence ${ }^{43,46,47}$

As important limitations of this study, we should highlight that the information was collected from secondary sources and that the information on the detailed history of the deaths' circumstances was not available in the reports evaluated. Moreover, the extrapolation of the conclusions should be considered with care, since the data were obtained from a specific geographic region. There are administrative and technical peculiarities involving the operation of different Legal Medical Institutes in the different Brazilian states and in other countries, which influence which cases are directed to necropsy, how necropsies are performed and how reports are made.

\title{
RES U M O
}

\begin{abstract}
Objetivo: avaliar o perfil epidemiológico dos óbitos por trauma abdominal no Instituto Médico Legal de Belo Horizonte. Métodos: estudo retrospectivo dos laudos de óbitos relacionados a trauma abdominal necropsiados no período de 2006 a 2011. Resultados: foram analisados 1888 laudos necroscópicos de trauma abdominal. O trauma penetrante foi mais comum que o contuso, e o decorrente de projéteis de arma de fogo mais prevalente que o relacionado a armas brancas. A maioria dos indivíduos era do sexo masculino, morena, solteira e ativa do ponto de vista ocupacional. A média etária foi de 34 anos. O homicídio foi a circunstância do óbito mais prevalente, seguido dos acidentes de trânsito, e quase a metade dos casos foi recebida no Instituto Médico Legal proveniente de uma unidade saúde. Os órgãos abdominais mais lesados no trauma penetrante foram o fígado e os intestinos, e no trauma contuso foram o fígado e o baço. A pesquisa de alcoolemia foi positiva em um terço das necropsias onde foi realizada. Cocaína e maconha foram as substâncias mais encontradas nos exames toxicológicos. Conclusão: nesta amostra houve predominância do trauma abdominal penetrante, em homens jovens, morenos e solteiros, sendo o fígado o órgão mais lesado.
\end{abstract}

Descritores: Autopsia. Medicina Legal. Homicídio. Traumatismos Abdominais.

\section{REFERENCES}

1. Gonsaga RAT, Rimoli CF, Pires EA, Zogheib FS, Fujino MVT, Cunha MB. Avaliação da mortalidade por causas externas. Rev Col Bras Cir. 2012; 39(4):263-7.

2. Waiselfisz JJ. Os jovens do Brasil: mapa da violência 2014 [Internet]. Brasília: Secretaria-Geral da Presidência da República: Secretaria Nacional de Juventude: Secretaria de Políticas de Promoção da Igualdade Racial; 2014. [citado 2017 jun 28]. Disponível em: http://www.mapadaviolencia.org. br/pdf2014/Mapa2014_JovensBrasil.pdf

3. Evans JA, van Wessem KJ, McDougall D, Lee KA, Lyons T, Balogh ZJ. Epidemiology of traumatic deaths: comprehensive population-based assessment. World J Surg. 2010;34(1):158-63.

4. Teixeira PG, Inaba K, Hadjizacharia P, Brown C, Salim $A$, Rhee $P$, et al. Preventable or potentially preventable mortality at a mature trauma center. 
J Trauma. 2007; 63(6):1338-46.

5. Parreira JG, Oliari CB, Malpaga JM, Perlingeiro JA, Soldá SC, Assef JC. Severity and treatment of "occult" intra-abdominal injuries in blunt trauma victims. Injury. 2016;47(1):89-93.

6. Parreira JG, Coimbra R, Rasslan S, Ruiz DE. Politraumatizados com trauma craniencefálico grave: importância das lesões abdominais associadas. Rev Col Bras Cir. 2001;28(5):336-41.

7. Jansen JO, Yule SR, Loudon MA. Investigation of blunt abdominal trauma. BMJ. 2008; 336(7650):938-42.

8. Diercks DB, Clarke S. Initial evaluation and management of blunt abdominal trauma in adults. Moreira ME, ed. Waltham (MA): UpToDate; c2016 [updated 2016 Jul 6; cited 2017 Jun 5]: Available from: http://www.uptodate.com/pt/home

9. Nishijima DK, Simel DL, Wisner DH, Holmes JF. Does this adult patient have a blunt intraabdominal injury? JAMA. 2012;307(14):1517-27.

10. Subedi N, Yadav BN, Jha S, Gurung S, Pradhan A. autopsy study of liver injuries in a tertiary referral centre of eastern Nepal. J Clin Diagn Res. 2013;7(8):1686-8.

11. Freire E, Freire MA, Malvezzi A. Trauma do abdome. In: Freire E. Trauma - a doença do século. São Paulo: Atheneu; 2001. p. 1513-36.

12. Colwell C, Moore EE. Moreira ME. Initial evaluation and management of abdominal stab wounds in adults. Moreira ME, ed. Waltham (MA): UpToDate; c2016 [updated 2016 Oct 3; cited 2017 Jun 5]: Available from: http://www. uptodate.com/pt/homeUpToDate

13. Colwell C, Moore EE. Section Editor: Moreira ME. Initial evaluation and management of abdominal gunshot wounds in adults. Moreira ME, ed. Waltham (MA): UpToDate; c2016 [updated 2016 Dec 3; cited 2017 Jun 5]: Available from: http:// www.uptodate.com/pt/homeUpToDate

14. Hercules HC. Causa Jurídica da Morte. In: Hercules HC. Medicina legal - texto e atlas. 2a ed. São Paulo: Atheneu; 2014. p.123-43.

15. Brasil. Presidência da República. Casa Civil Subchefia para Assuntos Jurídicos. Decreto-lei 3.689, de 03 de outubro de 1941 - Código de
Processo Penal. D.O.U de 13 de outubro de 1941 (retificado em 24 de outubro de 1941). Acesso em 2017 Mar 26. Disponível em: http://www. planalto.gov.br/ccivil_03/decreto-lei/Del3689. htm.

16. Conselho Federal de Medicina. Resolução número 1.779 de 05 de Dezembro de 2005 - Regulamenta a responsabilidade médica no fornecimento da Declaração de Óbito. D.O.U de 05 de dezembro de 2005; seção 1, p.121. Acesso em 2017 Mar 26. Disponível em: http://www.portalmedico.org. br/resolucoes/cfm/2005/1779_2005.htm.

17. Holder $Y$, Peden M, Krug E, Lund J, Gururaj G, Kobusingye $O$, editors. Injurysurveillanceguidelines. Geneva: World Health Organization; 2001. [cited 2017 May 5]. Available from: http://apps.who.int/ iris/bitstream/10665/42451/1/9241591331.pdf

18. Brasil. IBGE. Estimativas da população residente nos municípios brasileiros. [citado 2016 Jun 6]. Disponível em: http://www.ibge.gov.br

19. Kruel NF, Oliveira VL, Oliveira VL, Honorato RD, Pinatti BD, Leão FR. Perfil epidemiológico de trauma abdominal submetido à laparotomia exploradora. ABCD Arq Bras Cir Dig. 2007;20(2):106-10.

20. Leite S, Taveira-Gomes A, Sousa H. Lesão visceral em trauma abdominal: um estudo retrospetivo. Acta Med Port. 2013;26(6):725-30.

21. Subedi N, Yadav BN, Jha S, Paudel IS, Regmi R. A profile of abdominal and pelvic injuries in medico-legal autopsy. J Forensic Leg Med. 2013;20(6):792-6.

22. Zafar SN, Rushing A, Haut ER, Kisat MT, Villegas $C V$, Chi A, et al. Outcome of selective nonoperative management of penetrating abdominal injuries from the North American National Trauma Database. Br J Surg. 2012;99 Suppl 1:155S-64S.

23. Pimentel SK, Sawczyn GV, Mazepa MM, Rosa FGG, Nars A, Collaço IA. Fatores de risco para óbito no trauma abdominal fechado com abordagem cirúrgica. Rev Col Bras Cir. 2015;42(4):259-64.

24. Clark C, Mole CG, Heyns M. Patterns of blunt force homicide in the West Metropole of the City of Cape Town, South Africa. S Afr J Sci. 2017;113(5/6):1-6.

25. Waiselfisz JJ. Mapa da violência 2015: homicídios 
de mulheres no Brasil. Faculdade LatinoAmericana de Ciências Sociais. Brasília: FLACSO; 2015 [citado 2016 Jun 17]. Disponível em: http://www.mapadaviolencia.org.br/pdf2015/ MapaViolencia_2015_mulheres.pdf

26. Ben Khelil M, Farhani F, Harzallah H, Allouche $M$, Gharbaoui M, Banasr A, et al. Patterns of homicide in North Tunisia: a 10-year study (2005-2014). Inj Prev. 2017 Feb 9 [Epub ahead of print].

27. Araújo EM, Costa MCN, Hogan VK, Mota ELA, Araújo TM, Oliveira NF. Diferenciais de raça/cor da pele em anos potenciais de vida perdidos por causas externas. Rev Saúde Pública. 2009;43(3):405-41.

28. Maia PB. Vinte anos de homicídios no estado de São Paulo. São Paulo Perspec. 1999;13(4):121-9.

29. Batista $A S$, França $K C B$, Berdet $M$, Pinto $M A B$ Metropolização, homicídios e segurança pública na área metropolitana de Brasília: o município de Águas Lindas de Goiás. Soc Estado. 2016;31(2):433-57.

30. Guirra GCS, Souza LE, Moreau MS. Análise da distribuição espacial de homicídios na zona urbana de Ilhéus - BA. In: X Semana de Geografia da Universidade Estadual da Bahia (UESB). Anais... Ilhéus: UESB; 2011. p. 1-17 [citado em 2017 Jun 6]. Disponível em: http://www.uesb.br/eventos/ ebg/anais/2i.pdf

31. Benjamin E. Traumatic gastrointestinal injury in the adult patient. Bulger EM, ed. Waltham (MA): UpToDate; c2017 [updated 2017 Jan 27; cited 2017 Jun 5]: Available from: http://www. uptodate.com/pt/home

32. Watts DD, Fakhry SM; EAST Multi-Institutional Hollow Viscus Injury Research Group. Incidence of hollow viscus injury in blunt trauma: an analysis from 275,557 trauma admissions from the east multi-institutional trial. J Trauma. 2003; 54(2):28994. Erratum in: J Trauma. 2003;54(4):749.

33. Oncel D, Malinoski D, Brown C, Demetriades D, Salim A. Blunt gastric injuries. Am Surg. 2007;73(9):880-3.

34. Bruscagin V, Coimbra R, Rasslan S, Abrantes WL, Souza HP, Neto G, et al. Blunt gastric injury. A multicentre experience. Injury. 2001;32(10):7614.
35. Nance ML, Peden GW, Shapiro MB, Kauder DR, Rotondo MF, Schwab CW. Solid viscus injury predicts major hollow viscus injury in blunt abdominal trauma. J Trauma.1997;43(4):618-22.

36. Wilson RF, Walt AJ. Injuries do the liver and biliary tract. In: Wilson RF, Walt AJ. Management of trauma: pitfalls and practice. 2nd ed. Baltimore: Lippincott Williams \& Wilkins; 1996. p. 449-72.

37. Starling SV, Azevedo $\mathrm{Cl}$, Santana AV, Rodrigues $\mathrm{BL}$, Drumond DAF. Lesão hepática isolada por arma de fogo: é possível realizar tratamento não operatório? Rev Col Bras Cir. 2015;42(4):238-43.

38. Fraga GP, Mantovani M, Hirano ES, Leal RF. Trauma da Veia Porta. Rev Col Bras Cir. 2003;30(1):43-50.

39. Sinagawa DM, Godoy CD, Ponce JC, Andreuccetti G, Carvalho DG, Muñoz DR, Leyton V. Uso de álcool por vítimas de morte violenta no Estado de São Paulo. Saúde, Ética \& Justiça. 2008;13(2):6571.

40. Andreuccetti G, Carvalho HB, Ponce JC, Carvalho DG, Kahn T, Muñoz DR, et al. Alcohol consumption in homicide victims in the city of São Paulo. Addiction. 2009;104(12):1998-2006.

41. Spitz WU. Forensic aspects of alcohol. In: Spitz WU, Spitz DJ. Spitz and Fisher's medicolegal investigation of death: guidelines for the application of pathology to crime investigation. 4th ed. Springfield: Charles C Thomas; 2006. p. 1218-29.

42. Minayo MCS, Deslandes SF. A complexidade das relações entre drogas, álcool e violência. Cad Saúde Públ. 1998;14(1):35-42.

43. Drumond EF, Souza HNF, Hang-Costa TA. Homicídios, álcool e drogas em Belo Horizonte, Minas Gerais, Brasil, 2000-2009. Epidemiol Serv Saúde. 2015;24(4):607-13.

44. Kuhns JB, Wilson DB, Maguire ER, Ainsworth SA, Clodfelter TA. A meta-analysis of marijuana, cocaine and opiate toxicology study findings among homicide victims. Addiction. 2009;104(7):1122-31.

45. Tardiff K, Marzuk PM, Leon AC, Hirsch CS, Stajic $M$, Portera L, et al. Homicide in New York City. Cocaine use and firearms. JAMA. 1994;272(1):436. 
46. Sheehan CM, Rogers RG, Williams GW 4th, Boardman JD. Gender differences in the presence of drugs in violent deaths. Addiction. 2013;108(3): 547-55. Erratum in: Addiction. 2013;108(6):1176.

47. Santos ZMSA, Farias FLR, Vieira LJVS, Nascimento SCO, Albuquerque VLM. Agressão por arma branca e arma de fogo interligada ao consumo de drogas. Texto Contexto Enferm. 2004;13(2):22632.
Recebido em: 30/06/2017

Aceito para publicação em: 27/07/2017

Conflito de interesse: nenhum.

Fonte de financiamento: nenhuma.

Endereço para correspondência:

Leonardo Santos Bordoni

E-mail: leonardosantosbordoni@gmail.com / polyannabordoni@gmail.com 